\title{
Lung Small Cell Carcinoma by AJCC v7 Stage
}

National Cancer Institute

\section{Source}

National Cancer Institute. Lung Small Cell Carcinoma by A/CC v7 Stage. NCI Thesaurus. Code C136496.

A term that refers to the staging of small cell lung carcinoma, following the rules of the TNM AJCC v7 classification system. 